\title{
Cognitive-pragmatic features of ethno-specific vocabulary characterizing monetary relations in the German language
}

\author{
Mariya A. Kulkova - Albina R. Shaidullina
}

DOI: 10.18355/XL.2020.13.02.04

\begin{abstract}
The key problems of modern linguistics are the establishment and description of the relationship between the semantic foundations of the language, the national mentality, and the culture of a particular ethnic group. At this point, ethnospecific vocabulary is of great interest to linguists, as well as for representatives of cultural studies, sociology, and ethnography. In this regard, this article is aimed to identify the features of national currency nominations that have a number of quantitative and qualitative characteristics in the German language, which is manifested at the level of frequency of use, as well as in terms of combinability at the level of syntagmatics. The methodological basis of the study were the main provisions of the theory of cognitive linguistics and the use of corpus technologies in the analysis of lexical units. The author compared data from paremiographic sources with data from the German language corpus "Digitales Wörterbuch der deutschen Sprache" (DWDS) on ethnospecific lexical units with subsequent identification of cognitive-discursive features of the analyzed group of lexemes. The obtained data can be taken into account when describing the mechanisms of formation and maintenance of national identity, translation of norms and values in the German-speaking ethnocultural society.
\end{abstract}

Key words: paremiological unit, ethnospecific vocabulary, German language, corpus linguistics

\section{Introduction}

At the new stage of development of modern German studies, the following trends of linguistic research are noted: interdisciplinarity and integrativity, anthropo- and cultural-centricity, discursivity and explanationality. At the same time, the study of language manifestation, taking into account current scientific trends, is incomplete without the interaction of such phenomena as language, society, consciousness, and culture.

Today, the cognitive paradigm of scientific knowledge is being intensively developed in modern linguistic research (Fillmore, 1982; Lakoff, Jonson, 1980; Langacker, 1991; Talmy, 1977; Jackendoff, 1983; Demiankov, 1994; Dobrovol'skij, 2016; Zamaletdinov, Gabdrakhmanova, Zamaletdinova, 2018; Kibrik, 1992; Kibrik, 2003; Kubryakova, 2004a,b; Demiankov, Zabotkina, Poppel, 2017; Rakhilina, 2010; Boldyrev, 2000; Zakharov, Bogdanova, 2011, etc.). Cognitive-discursive research allows us to penetrate deeper into the value-semantic space of an individual, subjecting the surrounding world, represented by the cognitive signs of the code system of the language personality, to a detailed examination through the prism of the personal worldview (Maslova, 2011).

An important role in describing the language means of objectification of human mentality is played by ethnospecific vocabulary that covers a large language layer and reflects the national identity of the language, culture, and way of thinking of the people as a whole (Kayumova, Konopleva, Safina, 2014; Kulkova, Fattakhova \& Zinecker, 2015; Husnutdinov et al., 2019). Ethnic features of the verbalization of ideas about the world of a particular people are determined by the mentality, 
geographical, cultural, and historical prerequisites, spiritual and material values of representatives of a certain ethno-cultural society.

This article presents the results of a linguocognitive analysis of the realities of the material culture of the German people, and the founding is based on the example of the German-language proverbial material, as well as the corpus of the German language "Digitales Wörterbuch der deutschen Sprache" (DWDS).

Detailed consideration are subjected to ethnic-specific lexemes, which represent currency paremiologically and their implementation in the German language. The results of the linguistic analysis are supplemented by data obtained during the application of modern German-language corpus data. Studies on the analysis of language means of verbalization of the concept "Money" in German have already been conducted by a number of scientists (Safina, 2002; Fedyanina, 2005; Kamyshanchenko \& Nerubenko, 2012; Zalavina et al., 2019, etc.). Nevertheless, there is lack of scientific research devoted to the study of ethnospecific lexemes that nominates monetary units in the German-language paremiological discourse by using corpus technologies, which allows comparing the qualitative and quantitative characteristics of the studied German-language lexemes in different language registers on the material of a large array of texts.

\section{Research Methodology}

In the analysis of the paremiological corpus study, we have identified the following tokens are nominees of monetary relations, reflecting the specific ethno-cultural realities of German society: Pfennig, Groschen, Taler, Dukaten, Gulden, Heller, Batzen, Kreuzer, acting cohyponymy in relation to the hypernym Geld, nominator money in the aggregate and not related to ethno-specific vocabulary. However, in the course of the study, in some cases, we resort to paremiographic and corpus data using the Geld lexeme due to the high frequency of use and wide information content, which contributes to a deeper linguocognitive analysis of sogiponyms. It should be noted that in the German paremiological units (here and after referred to as PU), there are numbers of terms denoting monetary units, as well as a variety of their axiological characteristics.

According to the German explanatory dictionary Duden (Duden, 2003: 1202), the lexeme der Pfennig (pfenning) (mhd. pfenni(n)c, ahd. pfenning, pfentin), is etymologically related to the Latin word pannus 'piece of matter', which is explained by the fact that the fabric was previously used as a method of payment or exchange of goods. The pfenning was a German monetary unit that was used in monetary circulation as a small change from the 9th-10th centuries until 2002.

Der Heller (mhd. heller, haller comes from the name of the Swabian city Hall 'Halle,' where the coinage was made) was a bargaining chip of the German States in the Middle ages, as well as in Modern times (Duden, 2003: 740). The first coins contained silver; later Geller was minted from copper; the value and quality of the coin changed. In the 16 th century, 1 Geller was equated to $1 / 2$ pfenning.

Der Groschen (groschen) (mhd. grosse, mlat. grossus = Dickpfennig ' literal: fat pfenning', zu lat. grossus = dick 'thick') is a medium-denomination coin that was widely distributed in Central and Eastern Europe, including Germany, during the late middle Ages and Modern times (Duden 2003: 679-680). 1 penny was equal to ten pfennings.

Der Taler (Taler) (derived from the name of the Czech city Joachimstaler = Joachimstal) is the designation of one of the most valuable coins minted from silver, which was in circulation in European countries (Duden, 2003: 1560). In Germany, the Thaler was used until the mid-18th century.

Der Gulden (Gulden) (mhd. guldin, vom lat. guldin pfenni $(n) c=$ goldene Münze 'gold coin') represented a large monetary unit. The coin was originally minted in

XLinguae, Volume 13 Issue 2, April 2020, ISSN 1337-8384, ISSN 2453-711X 
gold, later in silver, and was used in circulation in Germany and other European countries from the 14th to the 19th centuries (Duden, 2003: 404).

Der Dukaten (Ducat) (derived from the Latin word ducatus 'Duchy') is a gold coin that was in circulation in European countries from the 13th to the 19th centuries (Duden, 2003: 689).

Der Kreuzer (Kreuzer) (niederl. kruiser $=$ hin und her fahrendes Schiff, mhd. kruizer $=$ Kriegsschiff - is the name of silver and copper coins that were in circulation from the 13th to the 19th centuries in the southern part of Germany, Austria, and Switzerland. It is named because the cross was depicted on one of its sides (Duden, 2003: 963).

Der Batzen (batzen) (derived from the batzen lexeme 'sticky, soft') denoted a coin that was in circulation in the 15th and 19th centuries in Switzerland, Austria, and Germany. In terms of cost, batzen occupied an intermediate position between Gulden and Kreuzer ( 1 batzen $=4$ kreuzers, 1 goldgulden $=72$ kreuzers) (Duden, 2003: 236).

From the point of view of verbalization of monetary relations in paremiological discourse, the most popular use is noted for the Pfennig and Taler tokens that nominate coins of low and high value: „Der eigene Pfennig zahlt am besten“ (Beyer, 1989: 196), „Der Pfennig ist gut angewandt, der einen Groschen erspart“ (Beyer, 1989: 196), „Ein ersparter Pfennig ist zweimal verdient“ (Beyer 1989: 196), „Vor dem Pfennig zieht man den Hut“ (Beyer, 1989: 196), „Wer den Pfennig nicht spart, kommt nicht zum Groschen“ (Beyer, 1989: 197), „Wer keine Pfennige hat, lästert die Dukaten" (Beyer, 1989: 197) u.a.

In some cases, both lexemes that enter into oppositivity relations are found in the paremic: „Besser heute ein Pfennig, als morgen ein Taler" (Beyer, 1989: 196), „Ein täglicher Pfennig gibt einen jährlichen Taler“ (Beyer, 1989: 196), „Wer den Pfennig nicht ehrt, ist des Talers nicht wert“ (Duden, 1998: 543), „Ein ehrlicher Pfennig ist besser als ein gestohlener Taler“ (Beyer, 1989: 196), „Des Talers Geheimnis sitzt im Pfennig“ (Beyer, 1989: 196).

\section{Results and Discussion}

We present the results of the analysis of the frequency of use of tokens that nominate monetary units in German paremias in the following table.

Table 1 . The frequency of use of lexical items, nominator of the monetary unit in the German paremias

\begin{tabular}{|l|l|}
\hline $\begin{array}{l}\text { The name of a lexeme denoting a } \\
\text { monetary unit in German }\end{array}$ & $\begin{array}{l}\text { Frequency of use in paremiological discourse } \\
\text { in quantitative and percentage ratio }\end{array}$ \\
\hline Geld & $143(53 \%)$ \\
\hline Pfennig & $58(21 \%)$ \\
\hline Taler & $19(7 \%)$ \\
\hline Gulden & $14(5 \%)$ \\
\hline Heller & $12(4 \%)$ \\
\hline Groschen & $12(4 \%)$ \\
\hline Batzen & $6(2 \%)$ \\
\hline Kreuzer & $3(1 \%)$ \\
\hline Dukaten & $1(0,4 \%)$ \\
\hline
\end{tabular}

As can be seen from the table, the high-frequency constituents of German paremias that characterize material and monetary relations are the lexemes Geld (143 PU), Pfennig (58 PU). The average frequency components of the analyzed group of paremias include the lexical units Taler (19 PU), Gulden (14 PU), Heller (12 PU), and Groschen (12 PU). The low-frequency components are the Batzen (6 PU), Kreuzer (3 $\mathrm{PU})$, and Dukaten (1 PU) tokens. 
In the case of German, it is possible to identify several similarities in terms of semantic groups of word-combinations characterizing the monetary unit. The positive connotation is observed in the following lexemes that enter into attributive relations with words-nominees of monetary units: viel Heller, viel Kreuzer, viele Pfennige, viel Geld, ein guter Heller, ein guter Pfennig, ein guter Gulden, das liebe Geld: „Viel Heller machen auch Geld“ (Simrock, 2003: 238), „Viel Kreuzer machen den Gulden“ (Simrock, 2003: 305), „Viele Pfennige machen einen Taler“ (Beyer, 1989: 196), „,Viel Geld, viel Freunde“ (Simrock, 2003: 180), „Es ist ein guter Heller, so einen Taler bringt" (Simrock, 2003: 238), „Es ist ein guter Pfennig, der einen Gulden erspart“ (Simrock, 2003: 402), „Es ist ein guter Pfennig, der hundert einbringt“ (Beyer, 1989: 196), „Es ist ein guter Gulden, der hundert erspart“ (Simrock, 2003: 216), „Das liebe Geld kann alles" (Simrock, 2003: 177) etc.

German paremias that characterize monetary units from the point of view of peyorative connotation include paremiological units containing the following phrases: keine Pfennige, kein Kreuzer, kein Gulden, kein Geld, klein Geld, böser Heller, böser Pfennig. A negative attitude towards money, especially small coins, is usually associated with the inability to accumulate a large amount: „Wer keine Pfennige hat, lästert die Dukaten“ (Beyer, 1989: 197), „Kein Kreuzer, kein Schweizer“ (Simrock, 2003: 305), „Wer den Kreuzer nicht achtet, wird keinen Gulden wechseln“ (Simrock, 2003: 305), „Wo kein Geld ist, da ist auch keine Vergebung der Sünden“ (Simrock, 2003: 177), „Klein Geld, kleine Arbeit“ (Simrock, 2003: 181), „Böser Heller, so einen Gulden schadet" (Simrock, 2003: 238), „Zwei böse Heller finden sich gern in einem Beutel“ (Simrock, 2003: 238), „Böser Pfennig kommt allzeit wieder“ (Simrock, 2003: 402), „Es ist ein böser Pfennig, der einen Gulden schadet“ (Simrock, 2003: 402) etc.

In paremiological picture of the world of the German language, we find a reflection of the value category of the German mentality associated with abundance and strong financial position. Proverbs give emphasis to success, prosperity, good friendships, understanding when you have a large amount of money: „Viel Geld - viel Freunde“ (Simrock, 2003: 180), „Hat der Bauer Geld, hat's die ganze Welt“ (Beyer, 1989: 106), „Geld regiert die Welt" (Beyer, 1989: 106), „Wer Geld hat, wird überall verstanden“ (Beyer, 1989: 106), „Das liebe Geld kann alles“ (Simrock, 2003: 177).

The value of friendship, which is a more important priority in relation to money, is reflected in the following PU: "Besser in der Tasche kein Geld, als ohne Freunde in dieser Welt” (Beyer, 1989: 106).

In the German-language paremiological discourse, the relevance of monetary units not only of large but also of small denomination is indicated, which reflects the frugality of the German people, which is one of the key characteristics of this linguistic culture: "Viel Heller machen auch Geld" (Simrock, 2003: 238).

At the same time, the paremiological material also describes the negative consequences of big money: the breakup of friendly relations, the adoption of hasty and unreasonable decisions, and the loss of a sense of responsiveness, harmony, and satisfaction from existing goods, calmness, and the presence of troubles. Proverbs "Geld macht stumm (taub)" (Beyer, 1989: 106), "Wo Geld redet, muß Verstand schweigen" (Beyer, 1989: 106), "Viel Geld - wenig Verstand" (Beyer, 1989: 106), „Beim Gelde hört die Freundschaft auf" (Beyer, 1989: 106), "Geld stillt keinen Hunger" (Beyer, 1989: 106), "Wenig Geld - wenig Sorge" (Beyer, 1989: 106), "Je mehr Geld, desto mehr Sorgen" (Beyer, 1989: 106) are examples.

Special attention in the paremiological corpus is paid to the economical attitude to money. The significant role of thrift as a key characteristic of German linguoculture is established in a number of proverbs. The accumulation of material wealth is described in German paremias according to the semantic model "from small to large": „Viele Pfennige machen einen Taler" (Beyer, 1989: 196), „Es ist ein guter Pfennig, der hundert einbringt“" (Beyer, 1989: 196), „Es ist ein guter Gulden, der hundert erspart“

XLinguae, Volume 13 Issue 2, April 2020, ISSN 1337-8384, ISSN 2453-711X 
(Simrock, 2003: 216), Ein guter Batzen, der einen Gulden erspart“ (Simrock, 2003: 59), „Viel Kreuzer machen den Gulden“ (Simrock, 2003: 305).

In the system of monetary relations verbalized in the German-language paremiological corpus, the following axiological characteristics of money are noted: "the ability to earn money quickly" (frisch Geld, ein geschwinder Batzen), "belonging to money" (der eigene Pfennig), "honestly earned / illegally acquired money" (ein ehrlicher Pfennig, ein ehrlicher Groschen, ein gestohlener Taler), "regularity of income (daily, annual)" (ein täglicher Pfennig, ein jährlicher Taler): „Frisch Geld, frischer Held“ (Simrock, 2003: 179), „Besser ein geschwinder Batzen als ein langsamer Sechser" (Simrock, 2003: 59), „Der eigene Pfennig zahlt am besten“ (Beyer, 1989: 196), „Ein ehrlicher Pfennig ist besser als ein gestohlener Taler" (Beyer, 1989: 196), „Ein ehrlicher Groschen ist besser als ein gestohlener Taler" (Beyer, 1989: 118), „Ein täglicher Pfennig gibt einen jährlichen Taler“ (Beyer, 1989: 196).

We present the syntagmatic relationships of tokens that nominate monetary relations in German PU in the form of the following table:

Table 2. Attribute relationships of tokens that nominate monetary units, in the proverbial corpus of the German language

\begin{tabular}{|l|l|l|l|l|l|l|l|l|l|l|}
\hline & $\begin{array}{l}\text { Batz } \\
\text { en }\end{array}$ & $\begin{array}{l}\text { D } \\
\text { uk } \\
\text { at } \\
\text { en }\end{array}$ & Geld & $\begin{array}{l}\text { Gros } \\
\text { chen }\end{array}$ & $\begin{array}{l}\text { Gul } \\
\text { den }\end{array}$ & $\begin{array}{l}\text { Hell } \\
\text { er }\end{array}$ & $\begin{array}{l}\text { Kre } \\
\text { uzer }\end{array}$ & $\begin{array}{l}\text { Pfen } \\
\text { nig }\end{array}$ & $\begin{array}{l}\text { Ta } \\
\text { ler }\end{array}$ \\
\hline 1 & alt & & & + & & & & & & \\
\hline 2 & böse & + & & & & & + & & + & \\
\hline 3 & ehrlich & & & & + & & & & + & \\
\hline 4 & eigen & & & & & & & & + & \\
\hline 5 & erspart & & & & & & & & + & \\
\hline 6 & frisch & & & + & & & & & & \\
\hline 7 & geschwind & + & & & & & & & & \\
\hline 8 & gestohlen & & & & & & & & & + \\
\hline 9 & gut & + & & & & + & + & & + & \\
\hline 10 & jährlich & & & & & & & & & + \\
\hline 11 & kein & & & + & & & & & + & \\
\hline 12 & klein & & & + & & & & & & \\
\hline 13 & lieb & & & + & & & & & & \\
\hline 14 & täglich & & & & & & & & + & \\
\hline 15 & $\begin{array}{l}\text { versproch } \\
\text { en }\end{array}$ & & & & & + & & & & \\
\hline 16 & viel & & & + & & & + & & + & \\
\hline
\end{tabular}

Using the electronic corpus of the German language DWDS allows us to present systematic data on the quantitative indicators of lemmas that nominate monetary relations in the German language in table 3.

Table 3. The frequency of use of lexical items, nominating monetary units, in the electronic corpus of the German language DWDS

\begin{tabular}{|l|l|l|}
\hline Lemma & $\begin{array}{l}\text { Absolute and relative frequency } \\
\text { (ipm) in the main corpus of the } \\
\text { DWDS (1900-1999) }\end{array}$ & $\begin{array}{l}\text { Absolute and relative } \\
\text { frequency (ipm) in the } \\
\text { German-language DWDS text } \\
\text { archive }(1473-1927)\end{array}$ \\
\hline Geld & $17245(142,05)$ & $40689(185,95)$ \\
\hline
\end{tabular}




\begin{tabular}{|l|l|l|}
\hline Pfennig & $2129(17,54)$ & $3013(13,77)$ \\
\hline Taler & $698(5,75)$ & $7882(36,02)$ \\
\hline Gulden & $1044(8,60)$ & $5059(23,12)$ \\
\hline Heller & $491(4,04)$ & $1548(7,07)$ \\
\hline Groschen & $729(6,00)$ & $2062(9,42)$ \\
\hline Batzen & $3(0,02)$ & $403(1,84)$ \\
\hline Kreuzer & $4(0,03)$ & $2152(9,83)$ \\
\hline Dukaten & $137(1,13)$ & $2740(12,52)$ \\
\hline
\end{tabular}

As can be seen from the table, the ipm index of lemmas that nominate monetary units is much higher in the German-language archive of texts created in the 15-20 centuries when the studied monetary units were in circulation in Germany and Germanspeaking countries, compared to the corpus of DWDS containing texts of the 20th century (from 1900 to 1999).

The characteristic of syntagmatic relations of lemmas that nominate monetary relations in German is shown in table 4.

Table 4. Attribute relationships of lemmas that nominate monetary units, in the electronic corpus of the German language DWDS

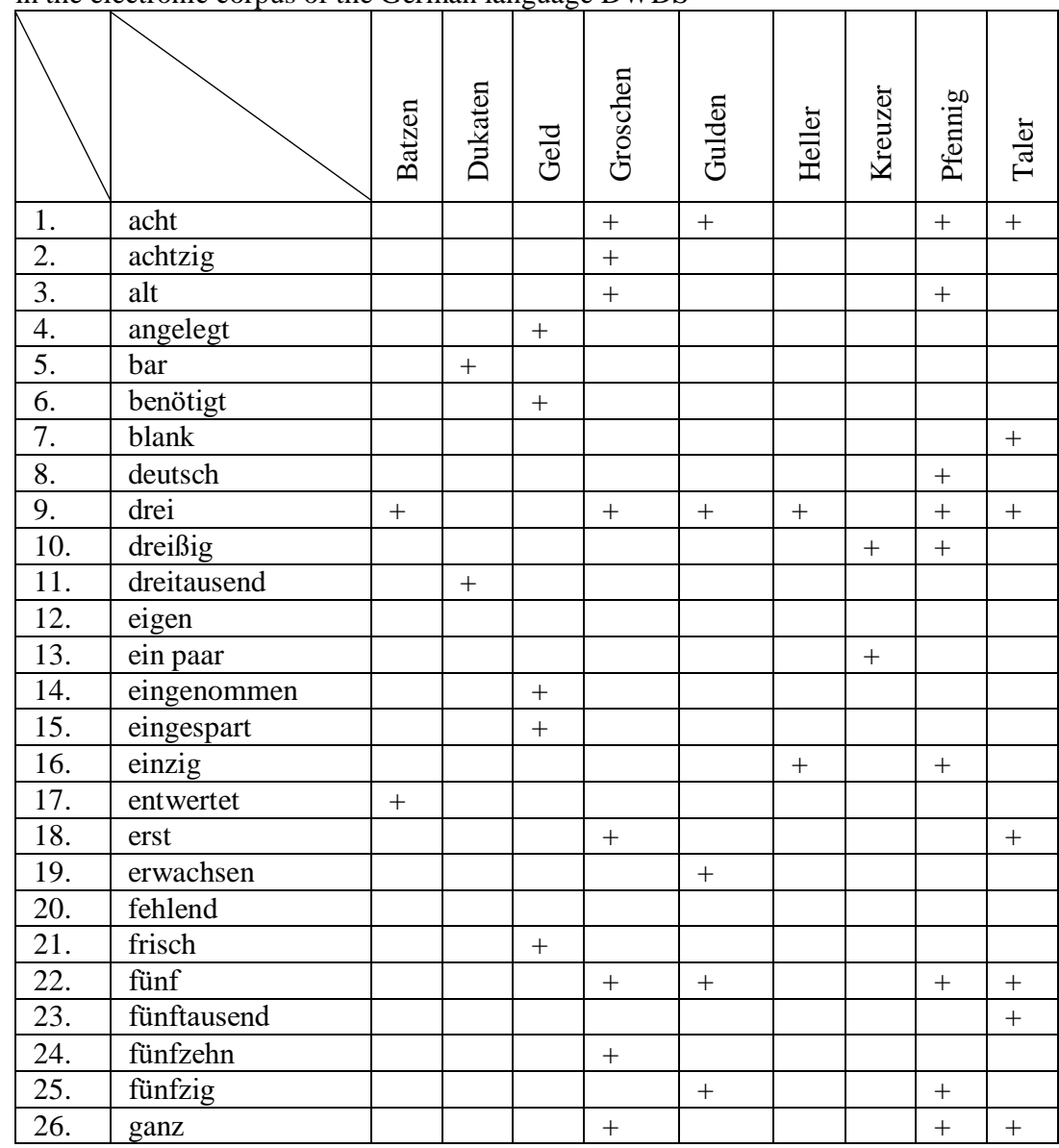

XLinguae, Volume 13 Issue 2, April 2020, ISSN 1337-8384, ISSN 2453-711X 


\begin{tabular}{|c|c|c|c|c|c|c|c|c|c|}
\hline 27. & geliehen & & + & & & & & & \\
\hline 28. & geschwind & & & & & & & & \\
\hline 29. & gespart & & + & & & & & & \\
\hline 30. & golden & + & & & & & & & + \\
\hline 31. & groß & & & & & & & & \\
\hline 32. & gut & & & + & & & & & \\
\hline 33. & halb & & & + & + & & & + & + \\
\hline 34. & hart & & & & + & & & & + \\
\hline 35. & holländisch & & & & + & & & & \\
\hline 36. & hundert & + & & & + & & & & + \\
\hline 37. & hunderttausend & & & & + & & & & + \\
\hline 38. & investiert & & + & & & & & & \\
\hline 39. & jung & & & & & + & & & \\
\hline 40. & knapp & & + & & & & & & \\
\hline 41. & letzt & & & + & & + & & + & + \\
\hline 42. & lieb & & + & & & & & & \\
\hline 43. & neu & & & + & & & & + & \\
\hline 44. & neun & & & & & & & & \\
\hline 45. & niederländisch & & & & + & & & & \\
\hline 46. & nötig & & + & & & & & & \\
\hline 47. & öffentlich & & + & & & & & & \\
\hline 48. & preußisch & & & & & & & & + \\
\hline 49. & rheinisch & & & & + & & & & \\
\hline 50. & rot & & & & & + & & & \\
\hline 51. & schmutzig & & + & & & & & & \\
\hline 52. & schnell & & + & & & & & & \\
\hline 53. & sechs & & & + & + & & + & + & \\
\hline 54. & sechzehn & & & + & & & & & \\
\hline 55. & sechzig & & & & & & & + & \\
\hline 56. & sieben & & & & + & & & + & \\
\hline 57. & tausend & + & & & + & & & & + \\
\hline 58. & teuer & & + & & & & & & \\
\hline 59. & verdient & & + & + & & & & & \\
\hline 60. & verloren & & & + & & & & & \\
\hline 61. & vier & & & + & + & & & + & + \\
\hline 62. & weit & & & & & & & + & \\
\hline 63. & wirklich & & & & & & & & + \\
\hline 64. & zehn & & & + & + & + & & + & + \\
\hline 65. & zusätzlich & & + & & & & & & \\
\hline 66. & zwanzig & & & + & + & & & + & \\
\hline 67. & zwei & & & + & + & + & + & + & + \\
\hline 68. & zweihundert & & & & & & & & + \\
\hline 69. & zwölf & & & & + & & & + & \\
\hline
\end{tabular}

These tables indicate a much larger volume and variable nature of left-hand collocates of lemmas that nominate monetary units in the DWDS corpus, which is formed by literary works, scientific and professional texts, and newspaper articles. Sixteen varieties of collocates were recorded in the paremiological corpus, while 69 different lemmas were found in the DWDS electronic corpus that denotes monetary units in German. The nature kolokatov revealed six cases of matches of attribute 
characteristics associated with the overall evaluation of reclamation and the love of money (gut, lieb), and the date of receipt of the money, the time spent to obtain a certain amount of money, supplies, deadline for receiving money (alt, eigen, frisch, geschwind). Differences are manifested in the attributive characteristics of nominees of monetary units in the paremiological corpus, related to the presence / absence of money (viel, kein, klein, jährlich), the nature of accumulation (erspart), the nature of receiving money (ehrlich). The electronic corpus mainly uses collocates that reflect the quantitative indicators of monetary units (acht, achtzig, drei, dreißig, dreitausend, fünf, fünftausend, hundert, hundertausend, neun, sechs, sechzehn, sechzig, sieben, tausend, vier, zehn, zwanzig, zwei, zweihundert, zwölf), or the territory of their distribution (deutsch, holländisch, niederländisch, preußisch, rheinisch). This fact is explained by the functional purpose of texts that use to analyzed words' forms. The communicative and pragmatic orientation of paremiological units is primarily associated with modeling human behavior, which is reflected in ridiculing human vices (greed, evasion of the law, obtaining material profit by dishonest means) or encouraging his virtues (thrift, economical and rational attitude to business management, hard work). In the artistic, scientific, professional, or commercial discourse, the reflection of the facts of objective reality plays a significant role, in our case, it is a description of commodity-money relations between quantitative indicators and country currency distribution.

\section{Conclusion}

Thus, comparison of data paroemiographic sources, as well as basic information about ethno-specific vocabulary of the German language allowed us to determine some features of nominations of the national currency units, having a number of quantitative and quality characteristics manifesting at the level of the frequency of use and in terms of co-occurrence relations at the level of syntagmatics. The identified cognitive-discursive features of lexemes that nominate monetary units in the German language can be taken into account when describing the mechanisms of formation and maintenance of identity, translation of norms and values in the German-speaking ethno-cultural society.

\section{Acknowledgments}

1. The work is performed according to the Russian Government Program of Competitive Growth of Kazan Federal University.

2. The study was conducted with the financial support of the grant of the government of the Republic of Tatarstan "Algarysh" in 2019.

\section{Bibliographic references}

BEYER, H. 1989. Sprichwörterlexikon. Nemeckie poslovicy i pogovorki: Sbornik. Moscow: Vysshaya shkola. ISBN: 978-5-7598-1102-2

BOLDYREV, N.N. 2000. Kognitivnaya semantika: (Kurs lektsiy po angl. filologii): Uchebnoje posobiye. Tambov: Izd-vo TGU. ISBN 978-5382-00494-5

DEMIANKOV, V.Z. 1994. Kognitivnaya lingvistika kak raznovidnost interpretiruyushchego podkhoda. In: Voprosy yazykoznaniya, n. 4, pp. 17-33. ISSN 0373-658X

DEMIANKOV, V.Z. - ZABOTKINA, V.I. - POPPEL, E. 2017. Reprezentatsiya sobytiy. Integrirovannyy podkhod s pozitsii kognitivnykh nauk: kollektivnaya monografiya. Moscow: Izdatelskiy dom YaSK. ISBN: 978-5-94457-309-4

DOBROVOL'SKIJ, D. 2016. Kognitive Aspekte der Idiom-Semantik. Studien zum Thesaurus deutscher Idiome. Tübingen: Narr. ISBN: 978-3-86057-368-6 
DUDEN. 2003. Deutsches Universalwörterbuch. 5., überarb. Auflage. Mannheim, Leipzig, Wien, Zürich: Dudenverlag. ISBN 10: 3411055057. ISBN 13: 9783411055050

DUDEN. 1998. Redewendungen und sprichwörtliche Redensarten. Band 11. Mannheim, Leipzig, Wien, Zürich: Dudenverlag. ISBN 3-411-04111-0

FEDYANINA, L.I. 2005. Kontsept Geld v nemetskoy yazykovoy kartine mira: $\mathrm{PhD}$ Thesis. Kemerovo.

FILLMORE, CH.J. 1982. Frame semantics. In: Linguistics in the morning calm: Selected papers from the SICOL. Seoul: Hanship.

HUSNUTDINOV, D.H. - SAGDIEVA, R.K. - SAYFULINA, F.S. - GATIN, R.G. 2019. Phraseological Units in the Tatar language containing the component of can (künel) (Soul). XLinguae, vol. 12, n. 2, pp. 41-50. ISSN 1337-8384

JACKENDOFF R.S. 1983. Semantics and cognition. Cambridge: Cambridge Mass. ISBN 026254027

KAMYSHANCHENKO, E.A. - NERUBENKO, N.V. 2012. Sopostavitelnyy analiz poslovits i pogovorok angliyskogo i nemetskogo yazykov. reprezentiruyushchikh kontsept «dengi». In: Filologicheskiye nauki. Voprosy teorii i praktiki, n. 1, pp. 78-80. ISSN 1997-2911

KAYUMOVA, A.R. - KONOPLEVA, N.V. - SAFINA, R.A. 2019. Lingvokulturologicheskie osobennosti frazeologicheskikh edinic $\mathrm{s}$ komponentom «ogon« v angliyskom, russkom, ispanskom, tatarskom i nemeckom yazykakh. In: XLinguae, vol. 12, n. 3, pp. 55-65. ISSN 1337-8384

KIBRIK, A.A. 2003. Analiz diskursa v kognitivnoy perspective: Doctoral Dissertation. Moscow: RAN IYa.

KIBRIK, A.E. 1992. Ocherki po obshchim i prikladnym voprosam yazykoznaniya: (universalnoye. tipovoye i spetsificheskoye v yazykoznanii). Moscow: Izd-vo MGU. ISBN 5-211-04924-1

KUBRYAKOVA, E.S. 2004a. Ob ustanovkakh kognitivnoy nauki i aktualnykh problemakh kognitivnoy lingvistiki. In: Voprosy kognitivnoy lingvistiki, n. 1, pp. 617. ISSN 1812-3228

KUBRYAKOVA, E.S. 2004b. Yazyk i znaniye: Na puti polucheniya znaniy o yazyke: Chasti rechi s kognitivnoy tochki zreniya. Rol yazyka v poznanii mira. Moscow: Yazyki slavyanskoy kultury. ISSN 1727-1630. ISBN 5-94457-174-8

KULKOVA, M.A. - FATTAKHOVA, N.N. - ZINECKER, TH. 2015. Paremiological text hermeneutics (in Russian and German). In: Journal of Language and Literature. May, vol. 6, n. 2, pp. 356-360. ISSN 0963-9470

LAKOFF, G. - JOHNSON, M. 1980. Metaphors We Live by. Chicago: University of Chicago Press.

LANGACKER, R. 1991. Concept, imadge and symbol: The cognitive basis of grammar. Berlin: Mouton de Gruyter. ISBN 3-11-012863-2

MASLOVA, V.A. 2011. Vvedeniye v kognitivnuyu lingvistiku: uchebnoye posobiye. 5-e izd. Moscow: Nauka. ISBN 978-5-02-033564-6.

RAKHILINA, E.V. 2010. Kognitivnyy analiz predmetnykh imen: semantika i sochetayemost. Izd. 2-e. ispr. i dop. Moscow: Azbukovnik. ISBN 978-5-91172-031-5

SAFINA, R.A. 2002. Frazeologicheskiye edinitsy. vyrazhayushchiye materialnodenezhnyye otnosheniya. v nemetskom i russkom yazykakh: PhD Thesis. Kazan: gos. un-t. Kazan.

SIMROCK, K. 2003. Die deutschen Sprichwörter. Düsseldorf: Albatros Verlag. ISBN 10: 3491960800 ISBN 13: 9783491960800

TALMY, L. 1977. Rubber-sheet cognition in language. In: CLS, vol. 13, pp. 612-628. ISSN 1997-2911

ZAKHAROV, V.P. - BOGDANOVA, S.YU. 2011. Korpusnaya lingvistika: uchebnik dlya studentov gumanitarnykh vuzov. Irkutsk: IGLU. ISBN 978-5-88267-316-0 
ZALAVINA, T.YU. - DERINA, N.V. - POLYAKOVA, L.S. - YUZHAKOVA, Y.V. 2019. Kontsept dengi $\mathrm{v}$ kontekste natsionalnykh lingvokultur. In: Vestnik Kemerovskogo gosudarstvennogo universiteta, vol. 21, n. 1, pp. 191-196. ISSN 20788975

ZAMALETDINOV, R.R. - GABDRAKHMANOVA, F.H. - ZAMALETDINOVA, G.F. 2018. The language nomination and the turkic conceptual system (on the material of the tatar language). In: National Academy of Managerial Staff of Culture and Arts HERALD, n. 3, pp.896-898. ISSN 2226-3209

Words: 4032

Characters: 26236 (14,58 standard pages)

Prof. Mariya A. Kulkova

Department of theory and practice of teaching foreign languages

Institute of Philology and Intercultural Communication

Kazan Federal University

420008 Kazan, Kremlyovskaya Street 18

Russian Federation

Mkulkowa@rambler.ru

Prof. Albina R. Shaidullina

Department of Foreign Languages

Almetyevsk State Oil Institute

2 Lenin Street,

423450 Almetyevsk,

Russian Federation

albina-plus@mail.ru 